\title{
Low amounts of trans $18: 1$ fatty acids elevate plasma triacylglycerols but not cholesterol and alter the cellular defence to oxidative stress in mice
}

\author{
Nadège Cassagno ${ }^{1}$, Antonio Palos-Pinto ${ }^{1}$, Pierre Costet $^{2}$, Dominique Breilh ${ }^{3}$, Michel Darmon ${ }^{1}$ and \\ Annie M. Bérard ${ }^{1} *$ \\ ${ }^{1}$ Laboratoire de Biochimie et de Biologie Moléculaire, EA no 3670, Centre Hospitalier Universitaire de Bordeaux, Université Victor \\ Ségalen Bordeaux 2, 146 rue Léo-Saignat, 33076 Bordeaux, France \\ ${ }^{2}$ Animalerie Transgénique, Université Victor Ségalen Bordeaux 2, 146 rue Léo-Saignat, 33076 Bordeaux, France \\ ${ }^{3}$ Pharmacie Hospitalière, Hôpital Haut-Lévêque, 33604 Pessac, France
}

(Received 23 September 2004 - Revised 15 March 2005 - Accepted 21 April 2005)

\begin{abstract}
Trans fatty acids are found mainly in processed foods. It has been shown that when their intake is high, total cholesterol, LDL-cholesterol and triacylglycerols are elevated, while HDL-cholesterol decreases. To evaluate a possible effect of these compounds, even in low amounts, C57Bl/6J mice were fed for 7 weeks a diet containing $13.6 \%$ energy as partially hydrogenated rapeseed oil-enriched diet (Trans diet). The Trans diet contained $3 \%$ energy as trans $18: 1$ fatty acid (elaidic acid). Control mice were on an isologous diet containing native rapeseed oil (Rapeseed diet) in which trans fatty acids were undetectable. Total, free and HDL-cholesterol as well as reverse cholesterol transport did not change. However, plasma triacylglycerol and VLDL levels increased. Hepatic gene expression in the Trans $v$. Rapeseed diet were compared using quantitative RT-PCR. The Trans diet produced a 2-3-fold elevation in mRNA of fatty acid synthase and microsomal transfer protein mRNA, explaining (at least in part) the observed increase in triacylglycerols and VLDL. In addition, mice on the Trans diet developed a deficiency in plasma vitamin $\mathrm{E}$ accompanied by a higher concentration of F2-isoprostanes, indicative of increased oxidative stress. The $78 \mathrm{kDa}$ glucose-related protein (GRP78) mRNA expression increased 3-4-fold in liver, suggesting that a response against apoptosis was provoked by lipid peroxidation.
\end{abstract}

Trans fatty acids: Hepatic triacylglycerol production: Reverse cholesterol transport: Oxidative stress

Trans fatty acids (TFA) are steric isomers of the common cis unsaturated fatty acids containing at least one double bond in the trans configuration. TFA are found in meat and dairy products at significant levels since they are intermediates in fatty acid $\beta$-oxidation, and also formed in the rumen by bacterial hydrogenation. But they are present at much higher levels in processed fried foods and cookies often made with hydrogenated vegetable oils (shortening). Evidence that use of TFA in food represents a risk for health has accumulated, and very recently a campaign has been launched by a US nutritional group to eliminate them from processed food recipes. TFA have already been cutdown in Denmark where guidelines issued by the government fix the maximal amount tolerated in foods. TFA intake has been associated with an increased risk of CHD. This correlated to increased plasma concentrations of total cholesterol, LDL-cholesterol, triacylglycerols, and decreased levels of HDL-cholesterol, which could explain their effect on CHD (Mensink \& Katan, 1990; Ascherio et al. 1999). These biochemical alterations appear to be somewhat proportional to intake (Lichtenstein et al. 1999). However, most of these studies were done with rather high concentrations of TFA and little is known about the possible impact on health of lower dietary intake of TFA as observed in Mediterranean countries. A better understanding of the effect of low levels of TFA on plasma lipoproteins and other biomarkers of CHD risk would provide insight into better prevention strategies.

In order to investigate this question, a first group of C57Bl/6J mice was fed the Trans diet, a diet supplemented with partially hydrogenated rapeseed oil, containing 3\% energy as trans 18:1 elaidic acid, and were compared with a second group of mice fed the Rapeseed diet, a diet supplemented with native rapeseed oil in which TFA are undetectable. Because of previous work showing that the adverse effect of TFA on cardiovascular risk was probably secondary to lipid metabolism alterations, we decided to explore in the present study the following parameters: plasma lipid and lipoprotein levels, reverse cholesterol transport and triacylglycerol-rich lipoprotein (TRL) metabolism as well as direct and indirect markers of oxidative stress.

\section{Materials and methods}

Mice and diets

C57B16 mice were obtained from Iffa Credo (L'Arbresle, France). They were housed in a full-barrier animal facility on a $12 \mathrm{~h}$ light/ 
dark cycle, with free access to food and water. The composition of the basal rodent diet (no. 113; UAR, Epinay-sur-Orge, France) was (w/w): $5 \%$ fat, $51 \%$ carbohydrate, $22 \%$ protein, $4 \%$ fibre, $6 \%$ minerals, and added vitamins A, B, D, E. Eightweek-old mice were placed for 7 weeks on UAR supplemented either with $5 \%$ native rapeseed oil diet (Rapeseed diet), or $5 \%$ partially hydrogenated rapeseed oil diet (Trans diet). Analysis of fatty acid composition of these isoenergetic diets, performed as previously described by Peuchant et al. (1989), is shown in Table 1 . The Trans diet brings $11 \mathrm{~g} / \mathrm{kg}$ trans $18: 1$, while this compound is not detectable in the Rapeseed diet. The two diets bring similar intakes in vitamin $\mathrm{E}$ since the bulk of this vitamin comes from the UAR diet: in $1 \mathrm{~kg}$ of Rapeseed diet, $7.5 \mathrm{mg}$ come from rapeseed oil (Favier et al. 1995) while $120 \mathrm{mg}$ come from UAR (UAR datasheet 113). Likewise UAR brings vitamins A, B, D (25 $200 \mathrm{U} / \mathrm{kg}, 63.91 \mathrm{mg} / \mathrm{kg}, 3000 \mathrm{U} / \mathrm{kg}$, respectively) in great excess to their amount in rapeseed oil.

Diets were made every 2 weeks, stored in individual packages at $4^{\circ} \mathrm{C}$ under $\mathrm{N}_{2}$, and changed twice daily in order to avoid oxidation. Mice did not lose weight and had normal hepatic tests (alanine aminotransferase, aspartate aminotransferase and lactate deohydrogenase) throughout the experiment. The use of the research protocol was in accordance with the French Ministry of Agriculture, Health and Animal Protection section (approval 33-04476).

\section{Plasma lipid and lipoprotein analysis}

Mice were fasted for $4 \mathrm{~h}$ and blood was drawn in tubes containing $4 \mathrm{mmol} / \mathrm{l}$ EDTA. Plasma samples were obtained by centrifugation at $2500 \mathrm{rpm}$ for $20 \mathrm{~min}$ at $4^{\circ} \mathrm{C}$, separated and divided into aliquots, then stored frozen $\left(-80^{\circ} \mathrm{C}\right)$ until analysed. Total cholesterol, triacylglycerol, free cholesterol and phospholipid as well as HDLcholesterol concentrations were measured as previously described by Le Morvan et al. (2002).

In order to obtain a plasma lipoprotein profile, we centrifuged pooled fresh mouse plasmas at $14000 \mathrm{rpm}$ for $20 \mathrm{~min}$ at $4{ }^{\circ} \mathrm{C}$ and applied $500 \mu \mathrm{l}$ clear supernatant to a fast protein liquid chromatography (FPLC) system with two superose columns connected in series (Pharmacia LKB, Orsay, France). Lipoproteins were eluted at $0.3 \mathrm{ml} / \mathrm{min}$ with $\mathrm{PBS}, \mathrm{pH} 7 \cdot 4$, containing $1 \mathrm{mmol} / \mathrm{l}$ EDTA and $0.02 \%$ sodium azide. After the first $10 \mathrm{ml}$ were eluted,

Table 1. Fatty acid composition of the experimental diets $(\mathrm{g} / \mathrm{kg}$ diet)

(Mean values with their standard errors)

\begin{tabular}{|c|c|c|c|c|}
\hline & \multicolumn{2}{|c|}{$\begin{array}{l}\text { Rapeseed diet } \\
\qquad(n 3)\end{array}$} & \multicolumn{2}{|c|}{$\begin{array}{l}\text { Trans diet } \\
\text { (n 3) }\end{array}$} \\
\hline & Mean & SEM & Mean & SEM \\
\hline $14: 0$ & $<1$ & & $1 \cdot 8$ & 1.5 \\
\hline $16: 0$ & $11 \cdot 8$ & $0 \cdot 8$ & 13.5 & $4 \cdot 1$ \\
\hline $16: 1$ & 0 & & 0 & \\
\hline $18: 0$ & $2 \cdot 7$ & 1.1 & $1 \cdot 7$ & $1 \cdot 3$ \\
\hline cis 18: 1 & 44.8 & 3.7 & $40 \cdot 6$ & $7 \cdot 9$ \\
\hline trans 18: 1 & 0 & & 11.5 & 0.2 \\
\hline $18: 2$ & $35 \cdot 9$ & 0.6 & 24.9 & $2 \cdot 3$ \\
\hline $18: 3$ & $4 \cdot 8$ & $2 \cdot 8$ & $2 \cdot 7$ & 0.3 \\
\hline $20: 5$ & $<1$ & & $<1$ & \\
\hline $22: 6$ & $<1$ & & $<1$ & \\
\hline
\end{tabular}

60 fractions $(0.51 \mathrm{ml}$ each) were collected. Total cholesterol and triacylglycerols were quantified in each fraction in order to establish an FPLC profile.

\section{Cell culture and cholesterol efflux}

Normal human embryonic lung fibroblasts (MRC-5 cells; Bioproducts for Biowhittaker, Gagny, France) were grown in 24-well plates containing Eagle's minimal essential medium (Gibco BRL, Cergy-Pontoise, France) supplemented with $10 \%$ bovine calf serum, $2 \mathrm{mmol} / \mathrm{l}$ glutamine, $100 \mathrm{IU} / \mathrm{ml}$ penicillin and $100 \mu \mathrm{g} / \mathrm{ml}$ streptomycin (Gibco BRL). When subconfluent, the cells were treated as previously described (De la Llera Moya et al. 1994; Bérard et al. 1997; Le Morvan et al. 2002). At least three culture wells were incubated with each plasma sample. Mouse plasmas used as cholesterol acceptors were kept at $-80^{\circ} \mathrm{C}$ until use. Eagle's minimal essential medium with $1 \%$ bovine serum albumin without acceptor was used as a blank. To standardize the cellular response obtained with different batches of cells and labelling medium, at least five aliquots of a standard plasma prepared from a pool of human plasmas were always included as a test sample.

\section{Lecithin cholesterol acyl transferase analysis}

Plasma lecithin cholesterol acyl transferase activity was determined as previously described by Chen \& Albers (1982) using $4 \mu 1$ mouse plasma.

\section{HDL-cholesterol ester metabolic studies}

Liposomes were generated by sonicating $\mathrm{L}-\alpha$-phosphatydylcholine (Sigma, L'Isle d'Abeau Chesnes, France), $\left[{ }^{3} \mathrm{H}\right]$ cholesteryl ester (Dupont-NEN, Paris, France) and butylated hydroxytoluene (Sigma) as described by Morton \& Zilversmit (1981) and incubated for $18 \mathrm{~h}$ at $37^{\circ} \mathrm{C}$ with $\mathrm{HDL}(2 \mathrm{mg}$ total protein) isolated from mice. Labelled lipoproteins were then isolated as previously described (Bérard et al. 1997; Le Morvan et al. 2002) and injected in the saphenous vein of mice fed either the Rapeseed diet or the Trans diet. Mice were pre-anaesthetized with ketamine $(50 \mathrm{mg} / \mathrm{kg})$ and xylazine $(14 \mathrm{mg} / \mathrm{kg})$. Blood sampling was performed at $5,15,30$, 60, 120, 240, 480 and 600 min after injection, and samples were analysed as previously described by Le Morvan et al. (2002).

\section{Oxidative stress biomarkers}

Plasma $\alpha$-tocopherol has been measured as previously described by Melin et al. (1992). Briefly, $100 \mu l$ plasma was mixed with absolute ethanol containing $0.1 \%$ ascorbic acid, and tocopherol acetate was used as internal standard. The vitamins were subsequently extracted in hexane. This extract was concentrated and dissolved in methanol. HPLC separations were performed on a $\mathrm{C} 18 \mu$ Bondapak $3.9 \times 300 \mathrm{~mm}$ column (Waters, Ontario, Canada) with a $1.5 \%$ deionized water-methanol mixture as the mobile phase. Monitoring was with a spectrophotometer detector (Waters $\lambda$ Max-481) at $290 \mathrm{~nm}$. $\alpha$-Tocopherol was quantified using appropriate extinction coefficients with standard obtained from Sigma.

Plasma F2-isoprostanes were analysed as described by the manufacturer (8-isoprostane EIA kit; Cayman Chemical Co., Ann Arbor, MI, USA). The intensity of the developed colour, 
determined spectrophotometrically at $405 \mathrm{~nm}$, was proportional to the amount of 8-isoprostane tracer bound to the well, which is inversely proportional to the amount of free 8-isoprostane present in the well during the incubation.

\section{RNA isolation and analysis}

Mouse livers were obtained from mice on the Rapeseed diet or the Trans diet. All samples were immediately put into a Trizol ${ }^{\circledR}$ solution (Gibco BRL) and stored at $-80^{\circ} \mathrm{C}$ pending RNA isolation. Total RNA was isolated according to Chomczynski \& Sacchi (1987). The amount of RNA was determined by measuring absorption at $260 \mathrm{~nm}$. Quality of the isolated RNA was controlled by the 260/ $280 \mathrm{~nm}$ ratio $(1.7-2.0)$ and by denaturing gel electrophoresis. For expression analysis, we performed RT-quantitative polymerase chain reaction (qPCR) as previously described by Bérard et al. (2004). TaqMan ${ }^{\circledR}$ probes (Roche molecular systems Inc, Pleesanton, CA, USA) were double labelled with the fluorescent reporter dye 6-carboxyfluorescein covalently linked to the $5^{\prime}$ end of the probe and the quencher dye 6-carboxytetramethylrhodamine attached to the $3^{\prime}$ end. qPCR was performed in 96-well reaction plates with optical caps. Fluorescence was continuously followed for each reaction. Specific cDNA amounts were normalized for ribosomal $18 \mathrm{~S}$ cDNA. The qPCR data are given as the mean (with their standard errors) of treated/untreated ratios of gene expression calculated from amplifications of cDNA prepared from individual mouse either on the Trans diet $(n 4)$ or the Rapeseed diet $(n 4)$ mice. Moreover, amplifications from each individual cDNA were performed in duplicate and the duplicate data matched closely, indicating that there was no technical problem with the qPCR; the means of the duplicates were used for the subsequent calculations (mean treated/untreated ratios with their standard errors).

\section{Statistical analysis}

An unpaired Student's $t$ test was used to compare values in groups of animals fed different diets. Statistical significance was defined as $P<0 \cdot 05$. Results are expressed as means with their standard errors.

\section{Results}

Characterization of plasma lipids in C57Bl/6J mice fed the trans diet

Analysis of plasma lipids in mice fed either the Rapeseed or the Trans diet for 7 weeks is shown in Table 2. There was no variation in plasma concentrations of total cholesterol, free cholesterol and HDL-cholesterol as well as phospholipids. However, plasma concentrations of triacylglycerols were significantly higher in mice on the Trans diet (76.4 (SEM 10.8) v. 58.9 $($ SEM $4 \cdot 2) \mathrm{mg} / \mathrm{dl}$ in the Rapeseed diet group, $P<0 \cdot 004$ ). In order to know the repartition of the triacylglycerols in plasma lipoproteins, they were analysed by FPLC (Fig. 1). We found in the Trans diet group an increase in VLDL particles which were enriched in triacylglycerols.

The trans diet stimulates genes involved in triacylglycerols and triacylglycerol-rich lipoprotein production

Figure 2 shows qPCR analysis of hepatic expression of genes involved in triacylglycerol and VLDL production. The Trans
Table 2. Lipids in C57BI6/J mice on the Trans diet for 7 weeks $†$ (Mean values with their standard errors)

\begin{tabular}{|c|c|c|c|c|}
\hline & \multicolumn{2}{|c|}{$\begin{array}{l}\text { Rapeseed diet } \\
\quad(n 10)\end{array}$} & \multicolumn{2}{|c|}{$\begin{array}{c}\text { Trans diet } \\
\quad(n 10)\end{array}$} \\
\hline & Mean & SEM & Mean & SEM \\
\hline Total cholesterol (mg/dl) & $80 \cdot 9$ & $7 \cdot 5$ & $80 \cdot 8$ & $10 \cdot 7$ \\
\hline Triacylglycerols (mg/dl) & 58.9 & $4 \cdot 2$ & $76 \cdot 4^{*}$ & $10 \cdot 8$ \\
\hline Phospholipids (mg/dl) & $118 \cdot 7$ & $7 \cdot 8$ & $120 \cdot 4$ & $8 \cdot 2$ \\
\hline Free cholesterol (mg/dl) & $18 \cdot 0$ & 1.6 & $18 \cdot 7$ & $1 \cdot 7$ \\
\hline Cholesterol ester (mg/dl) & $62 \cdot 9$ & $5 \cdot 9$ & $62 \cdot 1$ & 9.5 \\
\hline HDL-cholesterol (mg/dl) & $57 \cdot 7$ & $7 \cdot 4$ & $56 \cdot 3$ & $10 \cdot 9$ \\
\hline Total cholesterol : HDL-cholesterol & 1.42 & 0.11 & 1.49 & 0.20 \\
\hline
\end{tabular}

Mean value was significantly different from that of the rapeseed diet: ${ }^{\star} P<0.004$ †For details of diets and procedures, see Table 1 and p.347.

diet led to a 2-3-fold increase in mRNA of fatty acid synthase, the main rate-limiting enzyme in fatty acid production, and a 2-fold increase in mRNA of the sterol response element binding protein 1 (accession nb NM_011480), known to up-regulate fatty acid synthase transcription (Shinano et al. 1994). Moreover, microsomal transfer protein and apo B100 mRNA levels were higher in livers from mice fed the Trans diet. In contrast, 3hydroxy-3-methylglutaryl-CoA reductase gene expression did not change. Finally, we observed no changes in mRNA of the LDL receptor, a known TRL receptor. Interestingly, there was an increase in LDL receptor-related protein gene expression, known to be not only a TRL receptor but also a protease-clearing receptor involved in cellular remodelling.

\section{The trans diet does not alter reverse cholesterol transport}

Since metabolisms of hepatic TRL and HDL are linked, we explored the possibility that reverse cholesterol transport was altered by the Trans diet. We first performed efflux studies in fibroblasts loaded with unesterified cholesterol and incubated with mouse plasma at $5 \%$. Plasmas from mice fed the Trans diet $\left(\begin{array}{ll}n & 6\end{array}\right)$ were not less efficient in stimulating cholesterol efflux than those from mice on the Rapeseed diet $(n$ 6) $(18.8$ (SEM 0.5) v. 17.3 (SEM 0.3) \%,P>0.05). Then the cholesterol esterification rate was studied. Plasma lecithin cholesterol acyl transferase activity was not affected by the diets: 21.1 (SEM 1.5) $\mathrm{nmol} / \mathrm{ml}$ per $\mathrm{h}$ in the Trans group $(n 10)$ v. 25.4 (SEM 1.9) $\mathrm{nmol} / \mathrm{ml}$ per $\mathrm{h}$ in the Rapeseed group ( $n$ 10) $(P>0.05)$. Furthermore, the transfer of cholesteryl esters to the liver by HDL was as efficient in the two groups of mice: the fractional catabolic rate for HDL-cholesteryl esters was 6.34 (SEM 0.90) per d in mice on the Trans diet $(n$ 7) v. 5.40 (SEM 1.18) per $\mathrm{d}$ in mice on the Rapeseed diet $(n 7)(P>0.05)$, and the accumulation of $\left[{ }^{3} \mathrm{H}\right]$ cholesteryl esters derived from HDL in the liver was not altered by the diet (data not shown). qPCR analysis showed no change in liver expression of genes encoding the scavenger receptor class B1 (SR-B1; 1.1 (SEM 0.2) fold increase) and LDL receptor $(\times 1 \cdot 1(\operatorname{SEM} 0 \cdot 3))$, the two main routes for incorporation of HDL-cholesteryl esters in hepatocytes for elimination. Since cholesterol $7 \alpha$-hydroxylase is known to be the rate-limiting enzyme in the conversion of cholesterol to bile acids, we evaluated its hepatic mRNA level but did not find any change $(\times 1.3$ (SEM 0.6)). Likewise, the mRNA for liver $X$ receptor $\alpha$, a transcription factor up-regulating cholesterol $7 \alpha$-hydroxylase 


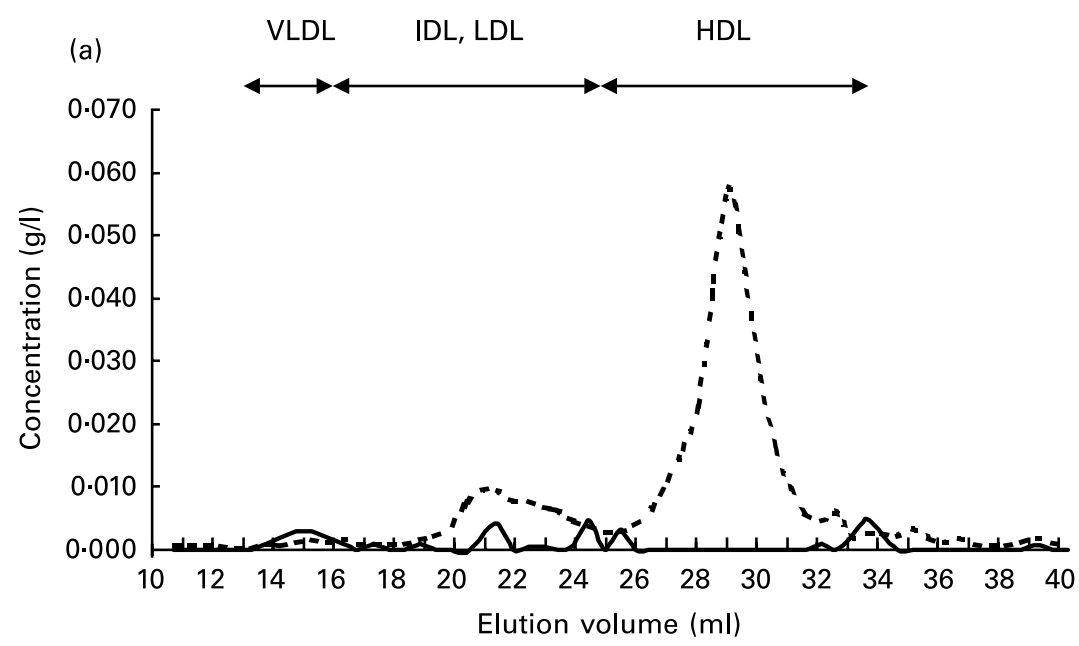

(b)

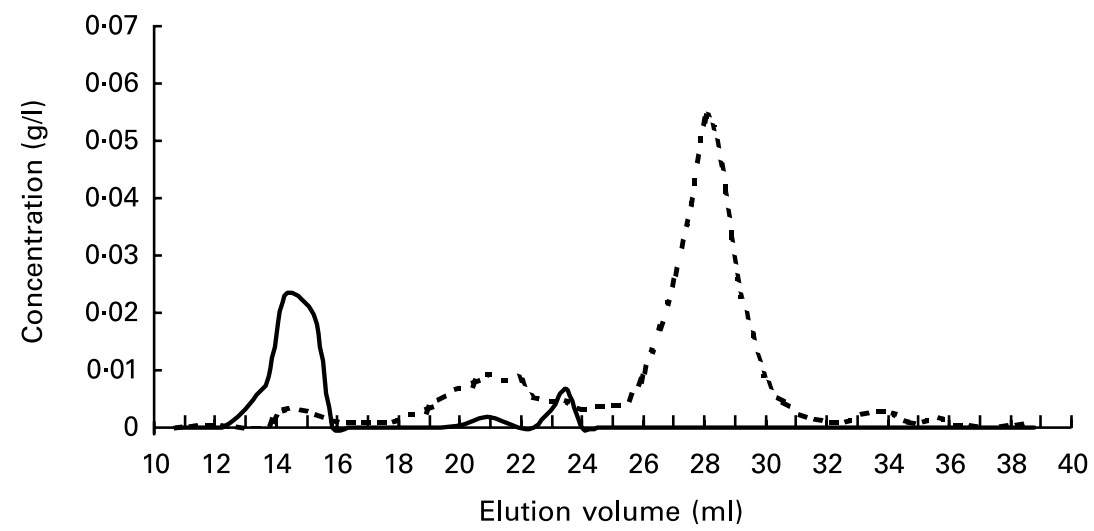

Fig. 1. Fast protein liquid chromatography (FPLC) analysis of plasma lipoproteins in mice. The cholesterol $(---)$ and triacylglycerol $(-)$ distribution in the plasma lipoproteins from mice on the Rapeseed diet (a) and on the Trans diet (b) after analysis by FPLC is shown. The elution positions of VLDL, intermediate density lipoprotein (IDL)/LDL and HDL lipoproteins are indicated. For details of procedures, pp. 347-348.

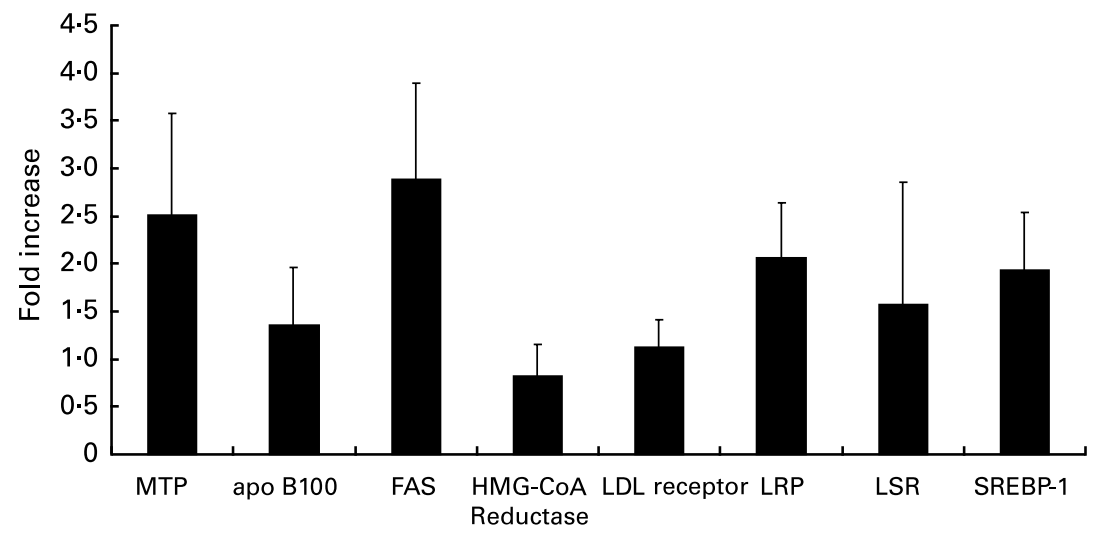

Fig. 2. Quantitative PCR ( $\mathrm{PPCR}$ ) data concerning genes involved in cholesterol metabolism. qPCR analysis shows the determination of the relative quantity of mRNA from individual livers of four mice on the Trans diet compared to mRNA from individual livers of four mice on the Rapeseed diet. Target and endogenous control (18S) amplifications have been performed in duplicate and results have been normalized to $18 \mathrm{~S}$. Values are means of the treated/untreated ratio of gene expression with their standard errors depicted by vertical bars. FAS, fatty acid synthase; HMG-CoA, 3-hydroxy-3-methylglutaryl-CoA; LRP, LDL receptorrelated protein; LSR, lipolysis stimulated receptor; MTP, microsomal transfer protein; SREBP-1, sterol response element binding protein 1. For details of diets and procedures, see Table 1 and pp. 347-348. 
gene (Peet et al. 1998), was not affected by the diet $(\times 1 \cdot 3$ (SEM $0 \cdot 1)$ ).

\section{The defence mechanisms against oxidative stress are altered by the trans diet}

We found a $30 \%$ decrease $(P<0.05)$ in the plasma concentration of vitamin $\mathrm{E}$ in mice fed the Trans diet (Table 3). Since the two diets brought an equal amount of vitamin $\mathrm{E}(120 \mathrm{mg} / \mathrm{kg}$ from the basal rodent diet), we interpreted this decrease as the result of its in vivo consumption secondary to an excessive production of free radicals. Actually, plasma F2-isoprostanes were $18 \%$ higher when mice were fed the Trans diet, showing a higher free radical injury. Moreover we found in the Trans group a 3-4-fold increase in the mRNA of $78 \mathrm{kDa}$ glucose-regulated protein (GRP78), an endoplasmic reticulum chaperone protein whose expression is induced during oxidative stress as a defence mechanism (Kaufman, 1999). Altogether the present results suggest that TFA provoke an increase in oxidative stress.

\section{Discussion}

The partial hydrogenation of liquid vegetable fats is used for producing vegetable shortening and margarine, and has been a major feature of food processing in Western countries during the second part of the 20th century. In this process, cis unsaturated fatty acids are converted to either saturated fats or a mixture of trans and cis isomers. As a result, the essential fatty acids of the fats added to the diet lose their biological activity while the trans isomers can compete with essential fatty acids in metabolic processes.

In the present study the Trans diet brings $11 \mathrm{~g} / \mathrm{kg}$ trans $18: 1$, while this compound is not detectable in the Rapeseed diet, and it is highly probable that the different biological effects of the two diets described in the present study depend mainly on this factor. Since the two diets differ also in PUFA it is not possible to conclude categorically that the differences observed are not caused (at least in part) by the differences in $18: 2$ (35.9 g in the Rapeseed diet $v .24 .9 \mathrm{~g}$ in the Trans diet) and $18: 3$ (4.8 g in the Rapeseed diet $v .2 .7 \mathrm{~g}$ in the Trans diet). However, this is very unlikely since in both diets these essential fatty acids are above the physiological requirement for rodents; i.e. $>1.30 \mathrm{~g} / \mathrm{kg}$ diet for $18: 3$ (Bourre et al. 1993) and $>12 \mathrm{~g} / \mathrm{kg}$ diet for $18: 2$ (Bourre et al. 1996). In that context of sufficient intake, the most important factor is the $18: 2 / 18: 3$ ratio and in both diets it is not far from 8 , the value recommended for rodents (Bourre et al. 1996).

Table 3. Oxidative biomarkers in C57BI6/J mice on the Trans diet for 7 weeks†

(Mean values with their standard errors)

\begin{tabular}{|c|c|c|c|c|}
\hline & \multicolumn{2}{|c|}{$\begin{array}{l}\text { Rapeseed diet } \\
(n 10)\end{array}$} & \multicolumn{2}{|c|}{$\begin{array}{l}\text { Trans diet } \\
(n 10)\end{array}$} \\
\hline & Mean & SEM & Mean & SEM \\
\hline Vitamin E (mg/dl) & $37 \cdot 3$ & $5 \cdot 5$ & $25 \cdot 9$ & $1.9^{\star \star}$ \\
\hline 8-Isoprostanes (ng/ml) & $38 \cdot 4$ & 3.9 & $46 \cdot 8$ & $3 \cdot 0^{*}$ \\
\hline GRP78 mRNA (fold change) ( $n$ 4) & - & & $3 \cdot 17$ & \\
\hline
\end{tabular}

GRP78, $78 \mathrm{kDa}$ glucose-related protein.

Mean values were significantly different from those of the rapeseed diet: ${ }^{\star} P<0.04$, ${ }^{* \star} P<0.05$.

†For details of diets and procedures, see Table 1 and pp. 347-348.
The increased intake of hydrogenated fats containing TFA has been associated with changes in lipid and lipoprotein levels, consistent with an increased risk of developing cardiovascular diseases (NCEP Experts, 1993). Based on the effects of TFA in metabolic studies and on the relationship between blood lipids and CHD incidence, it has been estimated that high intake of trans fat accounts for approximately 30000 premature deaths from CHD annually in the USA (Willett, 2001). Nevertheless, few studies have been conducted to evaluate effects of dietary intake of lower amounts of TFA as found in Mediterranean countries, on biological pathways involved in atherosclerosis progression such as lipoprotein metabolism and oxidative stress. The present study in mice showed that a diet supplemented with $5 \%$ partially hydrogenated rapeseed oil (w/w) containing $11.5 \%$ trans 18: 1 fatty acid (of total fats), had no effect on total cholesterol and non HDL-cholesterol, which contrasts with several studies in man (Mensink \& Katan, 1990; Zock \& Katan, 1992; Judd et al. 1994). Although mice, because of high levels of HDL, do not represent models that can be extrapolated for the study of lipoprotein metabolism in man, we performed these studies in mice because they are routinely used for studies of lipoprotein metabolism. Moreover, our findings of unchanged cholesterol levels in the Trans group of mice are in agreement with studies in hamsters (Nicolosi et al. 1998), monkeys (Kritchevsky et al. 1984) and one study in man (van de Vijver et al. 2000). On the other hand, the unchanged plasma HDL-cholesterol levels that we found are in agreement with several studies (Nestel et al. 1992; Judd et al. 1994). In the present study, we did not find any change in reverse cholesterol transport when mice were fed the Trans diet. HDL of both groups of mice showed the same capacity to participate in cholesterol uptake from cells and cholesterol esterification, which is in agreement with other studies (Lichtenstein et al. 2001; Gatto et al. 2002). The hepatic uptake of HDL-cholesteryl esters was not modified by the Trans diet. The Trans diet induced no change in SR-B1 and LDL receptor mRNA levels which is in agreement with the fact that, in the mouse, the removal of HDL-cholesteryl esters from the plasma is thought to be mainly due to SR-B1 present on cells of different organs including liver and also LDL receptor. Moreover, consistent with the present results, the hepatic transcriptional level of cholesterol $7 \alpha$-hydroxylase, the rate limiting enzyme for bile acid production and cholesterol excretion (Lavery \& Schibler, 1993; Stravitz et al. 1993), did not differ in the two groups of mice. Thus, we demonstrated, for the first time, that low dietary intake of trans 18:1 fatty acid has no deleterious effect on reverse cholesterol transport, an important mechanism by which HDL reduce the development of atherosclerosis.

Since there is increasing evidence that triacylglycerols and TRL carry a risk for coronary artery disease (Phillips et al. 1993; Hodis et al. 1994), it seemed promising to explore their metabolism. On the Trans diet, plasma concentrations of triacylglycerols significantly increased together with an elevation in VLDL-triacylglycerols. Our results suggest that this increase is probably due to an elevation in VLDL production rather than a decrease in recapture and degradation by the liver. Indeed microsomal transfer protein and apo B100 as well as fatty acid synthase hepatic mRNA levels increased when mice were fed the Trans diet. The present results seem logical since (1) microsomal transfer protein anchors lipids to the apo B100 molecule for VLDL synthesis and (2) VLDL carry fatty acids and cholesterol. Contrasting with the increase of fatty acid synthase mRNA, 
gene expression of 3-hydroxy-3-methylglutaryl-CoA reductase, the rate-limiting enzyme for cholesterol synthesis, was not modified as it has been described elsewhere (Cuchel et al. 1996; Matthan et al. 2000). Moreover, LDL receptor gene expression was not altered by the Trans diet, suggesting that this pathway for liver elimination of TRL (Beisiegel, 1995) was not impaired. On the other hand, the mRNA for receptor-related protein, also known to be able to capture TRL (Beisiegel, 1995), was increased 2 -fold. That might represent a response to increased apoptosis (Bartl et al. 2001), and might be related to our finding of an over-expression of the GRP78 gene encoding an endoplasmic reticulum chaperone protein whose expression is induced during oxidative stress (Kaufman, 1999). Its induction is required to maintain endoplasmic reticulum function, to facilitate protein folding and thus to protect cells from toxic consequences of oxidative stress. It has been suggested that GRP78 may protect the host cells against cell death by suppressing oxyradical accumulation and stabilizing mitochondrial functions (Liu et al. 1998; Rao et al. 2002). In the present study with mice, the Trans diet significantly induced a decrease in plasma vitamin $\mathrm{E}$ concentration and an increase in plasma F2-isoprostane level, both suggestive of an increased oxidative stress. In that respect, Hiramatsu \& Arimori (1988) suggested that serum triacylglycerol levels are correlated positively with superoxide anion production by leucocytes which in turn results in endothelial dysfunction (Bae et al. 2001), an early process of atherosclerosis. We thus propose the hypothesis that TFA could be proatherogenic through changes in redox state secondary to increased triacylglycerols. It would be interesting to examine whether higher intakes of TFA increase further oxidative stress.

The present study shows that even moderate amounts of TFA produce deleterious effects in mice. Extrapolation to man is not rigorous and only epidemiological studies will tell whether low amounts of trans fats are acceptable or not.

\section{Acknowledgements}

The authors thank Prof. Entressangles and Evelyne Peuchant for helping us with fatty acid analysis. This work was supported by ARCOL (Comité Français de Coordination des Recherches sur l'Athérosclérose et le Cholestérol, Saint-Maur, France).

\section{References}

Ascherio A, Katan MB, Zock PL, Stampfer MJ \& Willett WC (1999) Trans fatty acids and coronary heart disease. $N$ Engl $J$ Med 340, 1994-1998.

Bae JH, Bassenge E, Kim KB, Kin YN, Kin KS, Lee HJ, Moon KC, Lee MS, Park KY \& Schwemmer M (2001) Postprandial hypertriglyceridemia impairs endothelial function by enhanced oxidant stress. Atherosclerosis 155, 517-523.

Bartl MM, Luckenbach T, Bergner O, Ullrich O \& Koch-Brandt C (2001) Multiple receptors mediate apoJ-dependent clearance of cellular debris into nonprofessional phagocytes. Exp Cell Res 271, 130-141.

Beisiegel U (1995) Receptors for triglyceride-rich lipoproteins and their role in lipoprotein metabolism. Curr Opin Lipidol 6, 117-122.

Bérard AM, Dumon MF \& Darmon M (2004) Dietary fish oil up-regulates cholesterol 7alpha-hydroxylase mRNA in mouse liver leading to an increase in bile acid and cholesterol excretion. FEBS Lett 559, $125-128$.
Bérard A, Foger B, Remaley A, et al. (1997) High plasma HDL concentrations associated with enhanced atherosclerosis in transgenic mice overexpressing lecithin-cholesteryl acyltransferase. Nat $\mathrm{Med} \mathbf{3}$, $744-749$.

Bourre JM, Dumont O \& Durand G (1996) Does an increase in dietary linoleic acid modify tissue concentrations of cervonic acid and consequently alter alpha-linolenic requirements? Minimal requirement of linoleic acid in adult rats. Biochem Mol Biol Int 39, 607-619.

Bourre JM, Dumont O, Pascal G \& Durand (1993) Dietary alpha-linolenic acid at $1.3 \mathrm{~g} / \mathrm{kg}$ maintains maximal docosahexaenoic acid concentration in brain, heart and liver of adult rats. J Nutr 123, 1313-1319.

Chen CH \& Albers JJ (1982) Characterization of proteoliposomes containing apoprotein A-I: a new substrate for the measurement of lecithin: cholesterol acyltransferase activity. J Lipid Res 23, 680-691.

Chomczynski P \& Sacchi N (1987) Single-step method of RNA isolation by acid guanidinium thiocyanate-phenol-chloroform extraction. Anal Biochem 162, 156-159.

Cuchel M, Schwab US, Jones PJ, Vogel S, Lammi-Keefe C, Li Z, Ordovas J, McNamara JR, Schaefer EJ, Lichtenstein AH (1996) Impact of hydrogenated fat consumption on endogenous cholesterol synthesis and susceptibility of low-density lipoprotein to oxidation in moderately hypercholesterolemic individuals. Metabolism 45, 241-247.

De la Llera Moya M, Atger V, Paul JL, Fournier N, Moatti N, Giral P, Friday KE \& Rothblat G (1994) A cell culture system for screening human serum for ability to promote cellular cholesterol efflux. Relations between serum components and efflux, esterification, and transfer. Arterioscler Thromb 14, 1056-1065.

Favier J, Ireland-Ripert J, Toque C \& Feinberg M (1995) CIQUAL. Répertoire Général des Aliments. Table de Composition, 2nd ed, Paris: Lavoisier, Tec\&Doc.

Gatto LM, Lyons MA, Brown AJ \& Samman S (2002) Trans fatty acids affect lipoprotein metabolism in rats. J Nutr 132, $1242-1248$.

Hiramatsu K \& Arimori S (1988) Increased superoxide production by mononuclear cells of patients with hypertriglyceridemia and diabetes. Diabetes 37, 832-837.

Hodis HN, Mack WJ, Azen SP, Alaupovic P, Pogoda JM, LaBree L, Hemphill LC, Kramsch DM \& Blankenhorn DH (1994) Triglycerideand cholesterol-rich lipoproteins have a differential effect on mild/moderate and severe lesion progression as assessed by quantitative coronary angiography in a controlled trial of lovastatin. Circulation 90, 42-49.

Judd JT, Clevidence BA, Muesing RA, Wittes J, Sunkin ME \& Podczasy JJ (1994) Dietary trans fatty acids: effects on plasma lipids and lipoproteins of healthy men and women. Am J Clin Nutr 59, 861-868.

Kaufman RJ (1999) Stress signaling from the lumen of the endoplasmic reticulum: coordination of gene transcriptional and translational controls. Genes Dev 13, 1211-1233.

Kritchevsky D, Davidson LM, Weight M, Kriek NP \& du Plessis JP (1984) Effect of trans-unsaturated fats on experimental atherosclerosis in vervet monkeys. Atherosclerosis 51, 123-133.

Lavery DJ \& Schibler U (1993) Circadian transcription of the cholesterol 7 alpha hydroxylase gene may involve the liver-enriched bZIP protein DBP. Genes Dev 7, 1871-1884.

Le Morvan V, Dumon MF, Palos-Pinto A \& Bérard AM (2002) n-3 FA increase liver uptake of HDL-cholesterol in mice. Lipids. 37, 767-772.

Lichtenstein AH, Ausman LM, Jalbert SM \& Schaefer EJ (1999) Effects of different forms of dietary hydrogenated fats on serum lipoprotein cholesterol levels. N Engl J Med 340, 1933-1940.

Lichtenstein AH, Jauhiainen M, McGladdery S, Ausman LM, Jalbert SM, Vilella-Bach M, Ehnholm C, Frohlich J \& Schaefer EJ (2001) Impact of hydrogenated fat on high density lipoprotein subfractions and metabolism. J Lipid Res 42, 597-604.

Liu H, Miller E, van de Water B \& Stevens JL (1998) Endoplasmic reticulum stress proteins block oxidant-induced $\mathrm{Ca}^{2+}$ increases and cell death. J Biol Chem 273, 12858-12862.

Matthan NR, Ausman LM, Lichtenstein AH \& Jones PJ (2000) Hydrogenated fat consumption affects cholesterol synthesis in moderately hypercholesterolemic women. J Lipid Res 41, 834-839. 
Melin AM, Carbonneau MA, Thomas MJ, Maviel MJ, Perromat A \& Clerc M (1992) Relationship between dietary retinol and alpha-tocopherol and lipid peroxidation in rat liver cytosol. Food Addit Contam 9, 1-9.

Mensink RP \& Katan MB (1990) Effect of dietary trans fatty acids on high-density and low-density lipoprotein cholesterol levels in healthy subjects. $N$ Engl J Med 323, 439-445.

Morton RE \& Zilversmit DB (1981) A plasma inhibitor of triglyceride and cholesteryl ester transfer activities. J Biol Chem 256, 11992-11995.

NCEP Experts (1993) Summary of the second report of the NCEP expert panel on detection, evaluation, and treatment of high blood cholesterol in adults. JAMA 269, 3015-3023.

Nestel P, Noakes M, Belling B, McArthur R, Clifton P, Janus E \& Abbey M (1992) Plasma lipoprotein lipid and $\mathrm{Lp}$ [a] changes with substitution of elaidic acid for oleic acid in the diet. J Lipid Res 33, 1029-1036.

Nicolosi RJ, Wilson TA, Rogers EJ \& Kritchevsky D (1998) Effects of specific fatty acids $(8: 0,14: 0$, cis- $18: 1$, trans-18:1) on plasma lipoproteins, early atherogenic potential, and LDL oxidative properties in the hamster. J Lipid Res 39, 1972-1980.

Peet DJ, Turley SD, Ma W, Janorvski BA, Lobaccaro JM, Hammer RF \& Mangelsdorf DJ (1998) Cholesterol and bile acid metabolism are impaired in mice lacking the nuclear oxysterol receptor LXR alpha. Cell 93, 693-704.

Peuchant E, Wolff R, Salles C \& Jensen R (1989) One-step extraction of human erythrocyte lipids allowing rapid determination of fatty acid composition. Anal Biochem 181, 341-344.
Phillips NR, Waters D \& Havel RJ (1993) Plasma lipoproteins and progression of coronary artery disease evaluated by angiography and clinical events. Circulation 88, 2762-2770.

Rao RV, Peel A, Logvinova A, del Rio G, Hermel E, Yokota T, Goldsmith PC, Ellerby LM, Euerby HM \& Bredesen DE (2002) Coupling endoplasmic reticulum stress to the cell death program: role of the ER chaperone GRP78. FEBS Lett 514, 122-128.

Shimano H, Horton JD, Hammer RE, Shimomura I, Brown MS \& Goldstein JL (1996) Overproduction of cholesterol and fatty acids causes massive liver enlargement in transgenic mice expressing truncated SREBP-1a. J Clin Invest 98, 1575-1584.

Stravitz RT, Hylemon PB, Heuman DM, Hagey LR, Schteingart CD, Ton-Nu HT, Hofmann AF \& Vlahcevic ZR (1993) Transcriptional regulation of cholesterol 7 alpha-hydroxylase mRNA by conjugated bile acids in primary cultures of rat hepatocytes. $J$ Biol Chem 268, 13987-13993.

van de Vijver LP, Kardinaal AF, Couet C, et al. (2000) Association between trans fatty acid intake and cardiovascular risk factors in Europe: the TRANSFAIR study. Eur J Clin Nutr 54, 126-135.

Willett W (2001) Linus Pauling Institute Conferences. Trans and omega-3 fatty acids and CVD risk. http://lpi.oregonstate.edu/conference/ program2.html.

Zock PL \& Katan MB (1992) Hydrogenation alternatives: effects of trans fatty acids and stearic acid versus linoleic acid on serum lipids and lipoproteins in humans. J Lipid Res 33, 399-410. 